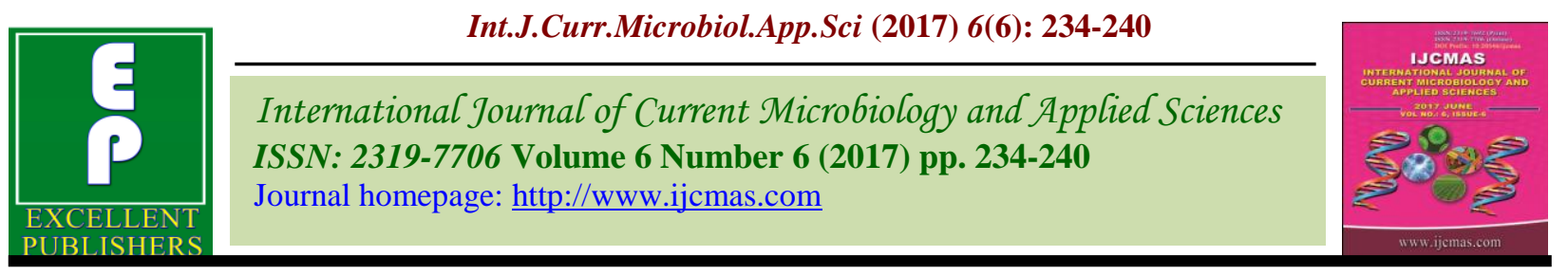

Original Research Article

https://doi.org/10.20546/ijcmas.2017.606.028

\title{
Availability of Macronutrients and their Relationship with some Soil Properties in Molisols of Udham Singh Nagar District of Uttarakhand, India
}

\author{
Vineet Kumar, Ajaya Srivastava, Shiv Singh Meena* and Sarvesh Kumar \\ Department of Soil Science, College of Agriculture, \\ GBPUA \& T, Pantnagar, U.S. Nagar, Uttarakhand 263145, India \\ *Corresponding author
}

A B S T R A C T

An investigation was carried out to study the distribution of available macronutrients (N, P, K and S) and their relationship with some physico-chemical

\section{Keywords}

Macronutrients, Physico-chemical properties, Fertilizer recommendations and Udham Singh Nagar

Article Info

Accepted:

04 May 2017

Available Online:

10 June 2017 properties of soil of different blocks of district Udham Singh Nagar (Uttarakhand).The soils of the district were found sufficient in Phosphorus, Potassium and Sulphur but low in available Nitrogen content. In general the macronutrients were correlated significantly and negatively with $\mathrm{pH}$ and positively with organic carbon of the soil. The values of the organic carbon, Alkaline $\mathrm{KMnO}_{4}$ extractable $\mathrm{N}$, Olsen's $\mathrm{P}$ and neutral normal Ammonium Acetate extractable $\mathrm{K}$ in the Udham Singh Nagar district ranged between 0.13-1.64 per cent, 125.44-338.68 kg N ha ${ }^{-1}, 7.34-76.70 \mathrm{~kg} \mathrm{P}_{2} \mathrm{O}_{5} \mathrm{ha}^{-1}$ and 66.08-271.04 $\mathrm{kg} \mathrm{K}_{2} \mathrm{O}$ $\mathrm{ha}^{-1}$, respectively. From the above findings it may be concluded that the soils of Udham Singh Nagar district are low in nitrogen, sufficient in phosphorus \& in potassium, Except Sitarganj, Jaspur and Bazpur samples were low in potassium, sufficient in sulphur except Rudrapur. These findings from present study can successfully be utilized for the larger parts of Tarai region of Uttarakhand as effective guide for efficient and balanced fertilizer recommendations.

\section{Introduction}

Soil plays a major role in determining the sustainable productivity of an agroecosystem. The sustainable productivity of a soil mainly depends upon its ability to supply essential nutrients to the growing plants. The deficiency of micronutrients has become major constraint to productivity, stability and sustainability of soils. The availability of some plant nutrients is greatly affected by soil $\mathrm{pH}$. The ideal soil $\mathrm{pH}$ is close to neutral, and neutral soils are considered to fall within a range from a slightly acidic $\mathrm{pH}$ of 6.5 to slightly alkaline $\mathrm{pH}$ of 7.5 . It has been determined that most plant nutrients are optimally available to plants within 6.5-7.5 $\mathrm{pH}$ range, also this range of $\mathrm{pH}$ is generally very compatible to plant root growth. Nitrogen (N), Potassium (K), and Sulphur (S) are major plant nutrients that appear to be less affected directly owing to variation in soil $\mathrm{pH}$ than many others, but still are to some extent.

Nitrogen is primarily responsible for vegetative growth. Nitrogen assimilation into amino acids is the building block for protein in the plant. It is a component of chlorophyll 
and is required for several enzyme reactions. Phosphorus is a major component in plant DNA and RNA. Phosphorus is also critical in root development, crop maturity and seed production. The role of potassium in the plant is indirect, meaning that it does not make up any plant part. Potassium is required for the activation of over 80 enzymes throughout the plant. It's important for a plant's ability to withstand extreme cold and hot temperatures, drought and pests. Potassium increases water use efficiency and transforms sugars to starch in the grain-filling process. $\mathrm{S}$ is essential in forming plant proteins because it is a constituent of certain amino acids. It is actively involved in metabolism of the B vitamins biotin and thiamine and co-enzyme A. S aids in seed production, chlorophyll formation, nodule formation in legumes, and stabilizing protein structure.

In Uttarakhand the farmers are not aware how $\mathrm{pH}, \mathrm{EC}$ and soil texture affects the availability of major nutrients in soil, which surely affects the crop growth and production of the crops. So keeping this fact in mind the present study "Availability of Macronutrients and their Relationship with some Soil Properties in Molisols of Udham Singh Nagar District of Uttarakhand" is done.

\section{Materials and Methods}

The present study was conducted on the soils of different villages of district Udham Singh Nagar which is situated in Uttarakhand state. The soil and plant sample (Wheat) were taken from each block of district, 6 soil samples were collected from a single block. RudrapurTanda Range, Gadarpur- Madnapur, JaspurTeerghari, Bazpur- Keshowala, SitarganjBaikunthapur, Kashipur- Dhakia Kalan and Khatima- Jhankat. Analysis of $\mathrm{pH}$ through $\mathrm{pH}$ meter, Electrical conductivity by EC meter, Organic carbon by Walkley and Black method. The samples were air dried, crushed on hard wooden slab with the help of wooden roller, passed through a $2 \mathrm{~mm}$ sieve and stored in a labeled polythene bags. Soil texture of soil was determined with the help of bouyoucous hydrometer method (Moodie et al., 1959). The $\mathrm{pH}$ of the soil was determined in 1:2 (soil:water) ratio after half an hour of equilibrium using glass electrode on a digital $\mathrm{pH}$ meter (Jackson, 1967). Electrical conductivity of the soil sample was measured in 1:2 (soil: water suspension) at $25^{\circ} \mathrm{C}$ using conductivity meter (Bower and Wilcox, 1965). Organic carbon content in the soil was determined by modified Walkley and Black method (1934) as described by Jackson (1967). Available nitrogen was estimated by alkaline $\mathrm{KMnO}_{4}$ method (Subbiah and Asija, 1956). Available phosphorus was extracted by Olsen's method (Olsen et al., 1954) using $0.5 \mathrm{M} \mathrm{NaHCO} 3(\mathrm{pH} 8.5)$ and developing the blue colour with ascorbic acid method of Murphy and Riley (1962). The intensity of blue colour was recorded on spectrophotometer at $882 \mathrm{~nm}$. Potassium was determined by using neutral ammonium acetate as extractant (Hanway and Hiedal, 1952). Potassium concentrations in the extracts were read by using flame photometer. Final values in soil were reported in $\mathrm{kg} \mathrm{ha}^{-1}$. The $0.15 \%$ calcium chloride extractable sulphur was determined by the method suggested by Williams and Steinbergs (1959). Most of the blocks were high in $\mathrm{pH}$ value; this might be due to presence of calcium carbonate and soluble salts and exchangeable sodium on exchange complex which gave soils higher $\mathrm{pH}$. The observed value of soil $\mathrm{pH}$ was quite comparable to that observed earlier by Kumar (1988) for soils of Siwaya (Meerut).

The high EC values possibly due to higher clay content might have encouraged greater retention of salt. On the basis of limits suggested by Muhr et al., (1965) for judging salt problem of soils, all the samples were found normal $\left(\mathrm{EC}<1.0 \mathrm{dSm}^{-1}\right)$. 
Organic carbon content in soils of Rudrapur block because the soils collected from the Tnada range which is a under forest area. Soils in low organic carbon (Khatima, 0.45 $\%)$ are possibly because of high temperature and good aeration in the soil which increased the rate of oxidation of organic matter.

\section{Results and Discussion}

\section{Nitrogen}

Available nitrogen extracted by alkalineKMnO4 method of the experimental district Udham Singh Nagar showed in table 1, varied from 125.44-338.68 $\mathrm{kg} \mathrm{N}$ ha $^{-1}$ with mean value of $187.26 \mathrm{~kg} \mathrm{~N} \mathrm{ha}^{-1}$. Block wise values ranged from 175.61 to $301.05 \mathrm{~kg} \mathrm{~N} \mathrm{ha}^{-1}$ with a mean of $202.79 \mathrm{~kg} \mathrm{~N} \mathrm{ha}{ }^{-1}$ in Rudrapur block, $150.52-338.68 \mathrm{~kg} \mathrm{~N}^{-1}$ with a mean of $209.06 \mathrm{~kg} \mathrm{~N} \mathrm{ha}{ }^{-1}$ in Gadarpur block, $125.44-288.51 \mathrm{~kg} \mathrm{~N}^{-1}$ with a mean of $181.88 \mathrm{~kg} \mathrm{~N} \mathrm{ha}^{-1}$ in Sitarganj block, 137.98$250.88 \mathrm{~kg} \mathrm{~N}^{-1}$ with a mean of 198.61$) \mathrm{kg} \mathrm{N}$ $\mathrm{ha}^{-1}$ in Khatima block, 125.44-238.33 kg N $\mathrm{ha}^{-1}$ with a mean of (165.16) $\mathrm{kg} \mathrm{N} \mathrm{ha}^{-1}$ in Jaspur block, $137.98-288.51 \mathrm{~kg} \mathrm{~N}^{-1}$ with a mean of $188.16 \mathrm{~kg} \mathrm{~N}^{-1}$ in Kashipur block and $150.52-200.70 \mathrm{~kg} \mathrm{~N}^{-1}$ with a mean of $165.16 \mathrm{~kg} \mathrm{~N} \mathrm{ha}^{-1}$ in Bazpur block.

\section{Phosphorus}

Available phosphorus extracted by Olsen's-P method of the experimental district Udham Singh Nagar showed in table 1 varied from 7.34 to $76.70 \mathrm{~kg} \mathrm{P}_{2} \mathrm{O}_{5}$ ha $^{-1}$ with mean value of $34.93 \mathrm{~kg} \mathrm{P}_{2} \mathrm{O}_{5} \mathrm{ha}^{-1}$. Block wise values ranged from 21.21 to $76.29 \mathrm{~kg} \mathrm{P}_{2} \mathrm{O}_{5} \mathrm{ha}^{-1}$ with a mean of $47.77 \mathrm{~kg} \mathrm{P}_{2} \mathrm{O}_{5} \mathrm{ha}^{-1}$ in Rudrapur block, 7.34-59.57 kg $\mathrm{P}_{2} \mathrm{O}_{5} \mathrm{ha}^{-1}$ with a mean of 22.44 $\mathrm{kg} \mathrm{P}_{2} \mathrm{O}_{5} \mathrm{ha}^{-1}$ in Gadarpur block, 16.32-40.80 $\mathrm{kg} \mathrm{P}_{2} \mathrm{O}_{5} \mathrm{ha}^{-1}$ with a mean of $27.77 \mathrm{~kg} \mathrm{P}_{2} \mathrm{O}_{5} \mathrm{ha}^{-1}$ in Sitarganj block, 7.54-58.55 kg $\mathrm{P}_{2} \mathrm{O}_{5} \mathrm{ha}^{-1}$ with a mean of $25.97 \mathrm{~kg} \mathrm{P}_{2} \mathrm{O}_{5} \mathrm{ha}^{-1}$ in Khatima block, 35.49-76.70 $\mathrm{kg} \mathrm{P}_{2} \mathrm{O}_{5} \mathrm{ha}^{-1}$ with a mean of $50.83 \mathrm{~kg} \mathrm{P}_{2} \mathrm{O}_{5} \mathrm{ha}^{-1}$ in Jaspur block, 31.82$62.42 \mathrm{~kg} \mathrm{P}_{2} \mathrm{O}_{5} \mathrm{ha}^{-1}$ with a mean of $40.25 \mathrm{~kg}$ $\mathrm{P}_{2} \mathrm{O}_{5} \mathrm{ha}^{-1}$ in Kashipur block and 11.01-65.69 $\mathrm{kg} \mathrm{P}_{2} \mathrm{O}_{5}$ ha $^{-1}$ with a mean of $29.51 \mathrm{~kg} \mathrm{P}_{2} \mathrm{O}_{5}$ ha ${ }^{1}$ in Bazpur block.

The higher value of $\mathrm{P}_{2} \mathrm{O}_{5}$ in some blocks of Udham Singh Nagar district might be due to good organic carbon, about neutral soil $\mathrm{pH}$ and less fixation of P. Similar reason was also suggested by Shah (1999) in some soils of western U.P.

\section{Potassium}

Available potassium extracted by neutral normal NH4OAC method showed in table 1 ranged from 66.08 to $271.04 \mathrm{~kg} \mathrm{~K} \mathrm{ha}^{-1}$ with mean value of $130 \mathrm{~kg} \mathrm{~K} \mathrm{ha}{ }^{-1}$. Block wise values ranged from $133.28-230.72 \mathrm{~kg} \mathrm{~K}^{-1}$ with a mean of (181.81) $\mathrm{kg} \mathrm{K} \mathrm{ha}^{-1}$ in Rudrapur block, 138.88-190.4 kg K ha ${ }^{-1}$ with a mean of $162.21 \mathrm{~kg} \mathrm{~K} \mathrm{ha}^{-1}$ in Gadarpur block, $70.56-120.96 \mathrm{~kg} \mathrm{~K} \mathrm{ha}^{-1}$ with a mean of 103.6 $\mathrm{kg} \mathrm{K} \mathrm{ha}^{-1}$ in Sitarganj block, $107.52-127.68 \mathrm{~kg}$ $\mathrm{K} \mathrm{ha}^{-1}$ with a mean of $119.84 \mathrm{~kg} \mathrm{~K} \mathrm{ha}^{-1}$ in Khatima block, 66.08-92.96kg K ha ${ }^{-1}$ with a mean of $75.41 \mathrm{~kg} \mathrm{~K} \mathrm{ha}{ }^{-1}$ in Jaspur block, $98.56-271.04 \mathrm{~kg} \mathrm{~K} \mathrm{ha}^{-1}$ with a mean of 171.53 $\mathrm{kg} \mathrm{K} \mathrm{ha}{ }^{-1}$ in Kashipur block and 71.68$117.6 \mathrm{~kg} \mathrm{~K} \mathrm{ha}^{-1}$ with a mean of $95.38 \mathrm{~kg} \mathrm{~N} \mathrm{ha}^{-}$ ${ }^{1}$ in Bazpur block.

Jaspur block have highest $\mathrm{K}$ content in whole district might be due to the higher content of organic carbon. Shah (1999) also suggested the same reason for the soils of western U.P.

\section{Sulphur}

The soil samples of Rudrapur block were have low in (Table 1) sulphur content ranged from 2.41-12.07 ppm with a mean value of $6.72 \mathrm{ppm}$. The soil samples of Gadarpur block were high in sulphur content ranged from 4.45 to $42.5 \mathrm{ppm}$ with a mean value of 21.5 
ppm. The soil samples of Sitarganj block were medium in sulphur content ranged from 9.32 to $31.40 \mathrm{ppm}$ with a mean value of 20.47 ppm. The soil samples of Khatima block were high in sulphur content ranged from 14.23 to $41.2 \mathrm{ppm}$ with a mean value of $24.04 \mathrm{ppm}$. The soil samples of Jaspur block were medium in sulphur content ranged from 4.46 to $22.31 \mathrm{ppm}$ with a mean value of 15.10 ppm. The soil samples of Kashipur block were medium in sulphur content ranged from 4.469 to $40.17 \mathrm{ppm}$ with a mean value of
14.34 ppm. The soil samples of Bazpur block were medium in sulphur content ranged from 8.92 to $25.14 \mathrm{ppm}$ with a mean value of 16.67 ppm.

The higher content of available $\mathrm{S}$ in Gadarpur and Khatima block might be due to higher $\mathrm{pH}$ and finer fractions of soil. The observed value of available $S$ was quite comparable to that observed earlier by Dixit (1992) for the soils of Ram ganga - Kosi interbasin.

Table.1 Availability of macronutrients in different blocks

\begin{tabular}{|c|c|c|c|c|}
\hline Blocks & $\begin{array}{c}\text { Alkaline } \\
\mathrm{KMnO}_{4}-\mathrm{N} \\
\left(\mathrm{kg} \mathrm{ha}^{-1}\right)\end{array}$ & $\begin{array}{l}\text { Olsen's-P } \\
\left(\text { kg ha }^{-1}\right)\end{array}$ & $\begin{array}{c}\mathrm{NH}_{4} \mathrm{OAc}-\mathrm{K} \\
\left(\mathrm{kg} \mathrm{ha}^{-1}\right)\end{array}$ & $\begin{array}{c}\text { S } \\
(\mathbf{p p m})\end{array}$ \\
\hline Rudrapur & $\begin{array}{c}175.61-301.05 \\
(202.79)\end{array}$ & $\begin{array}{c}25.69-76.29 \\
(47.77)\end{array}$ & $\begin{array}{c}133.28-230.72 \\
(181.81)\end{array}$ & $\begin{array}{c}2.41-12.07 \\
(6.72)\end{array}$ \\
\hline Gadarpur & $\begin{array}{c}150.52-338.68 \\
(209.06)\end{array}$ & $\begin{array}{c}7.34-59.57 \\
(22.44)\end{array}$ & $\begin{array}{c}138.88-190.4 \\
(162.21)\end{array}$ & $\begin{array}{c}4.45-42.5 \\
(21.5)\end{array}$ \\
\hline Sitarganj & $\begin{array}{c}125.44-288.51 \\
(181.88)\end{array}$ & $\begin{array}{c}16.32-40.80 \\
(27.77)\end{array}$ & $\begin{array}{c}70.56-120.96 \\
(103.6)\end{array}$ & $\begin{array}{c}9.32-31.40 \\
(20.47)\end{array}$ \\
\hline Khatima & $\begin{array}{c}137.98-250.88 \\
(198.61)\end{array}$ & $\begin{array}{c}7.54-58.55 \\
(25.97)\end{array}$ & $\begin{array}{c}107.52-127.68 \\
(119.84)\end{array}$ & $\begin{array}{c}14.23-41.2 \\
(24.04)\end{array}$ \\
\hline Jaspur & $\begin{array}{c}125.44-238.33 \\
(165.16)\end{array}$ & $\begin{array}{c}35.49-76.70 \\
(50.83)\end{array}$ & $\begin{array}{c}66.08-92.96 \\
(75.41)\end{array}$ & $\begin{array}{c}4.46-22.31 \\
(15.10)\end{array}$ \\
\hline Kashipur & $\begin{array}{c}137.98-288.51 \\
(188.16)\end{array}$ & $\begin{array}{c}31.82-62.42 \\
(40.25)\end{array}$ & $\begin{array}{c}98.56-271.04 \\
(171.73)\end{array}$ & $\begin{array}{c}4.46-40.17 \\
(14.34)\end{array}$ \\
\hline Bazpur & $\begin{array}{c}150.52-200.70 \\
(165.16)\end{array}$ & $\begin{array}{c}11.01-65.69 \\
(29.51)\end{array}$ & $\begin{array}{c}71.68-117.6 \\
(95.38)\end{array}$ & $\begin{array}{c}8.92-25.14 \\
(16.67)\end{array}$ \\
\hline $\begin{array}{c}\text { Udham Singh } \\
\text { Nagar }\end{array}$ & $\begin{array}{c}125.44-338.68 \\
(187.26)\end{array}$ & $\begin{array}{c}7.34-76.70 \\
(34.93)\end{array}$ & $\begin{array}{c}66.08-271.04 \\
(130)\end{array}$ & $\begin{array}{c}2.41-42.5 \\
(17.42)\end{array}$ \\
\hline
\end{tabular}

Table. 2 Correlation of soil properties with nutrient status in the soils of Udham Singh Nagar

\begin{tabular}{|c|c|c|c|c|}
\hline Soil properties & $\mathbf{N}$ & $\mathbf{P}$ & $\mathbf{K}$ & $\mathbf{S}$ \\
\hline pH & 0.026 & $-0.456^{*}$ & -0.158 & -0.051 \\
\hline EC & -0.043 & -0.397 & 0.166 & 0.180 \\
\hline O. C. & 0.124 & $0.335^{*}$ & 0.071 & -0.119 \\
\hline Clay & -0.028 & $-0.378^{*}$ & 0.218 & -0.142 \\
\hline Silt & 0.072 & -0.056 & 0.047 & 0.104 \\
\hline Sand & -0.066 & 0.262 & -0.167 & -0.040 \\
\hline
\end{tabular}




\section{Nutrient status}

As shown in table 2, in soils of Udham Singh Nagar District of Uttarakhand, the soil $\mathrm{pH}$ showed significant and negative correlation with available $\mathrm{P}(\mathrm{r}=-0.456)$ at 5 percent level of significance, positive non-significant correlation with $\mathrm{N}(\mathrm{r}=0.026)$ and negative non-significant correlation with $\mathrm{K}(\mathrm{r}=-0.158)$ and $\mathrm{S}(\mathrm{r}=-0.051)$. The electrical conductivity also showed non-significant and negative correlation with available $\mathrm{P}(\mathrm{r}=-0.397)$, positive non-significant correlation with $\mathrm{K}$ ( $\mathrm{r}$ $=0.166)$ and $\mathrm{S}(\mathrm{r}=0.180)$ and negative nonsignificant correlation with $\mathrm{N}(\mathrm{r}=-0.0430)$. The organic carbon showed positive and nonsignificant correlation with available $\mathrm{N}(\mathrm{r}=$ $0.124), \mathrm{K}(\mathrm{r}=0.071)$, negative and nonsignificant correlation with $S(r=-0.119)$ and significant positive correlation with $\mathrm{P}(\mathrm{r}=$ $-0.335)$ at 5 percent level of significance.

The clay showed negative and significant correlation with available $\mathrm{P}(\mathrm{r}=-0.378)$, negative non-significant correlation with $\mathrm{N}$ $(\mathrm{r}=-0.028), \mathrm{S}(\mathrm{r}=-0.142)$ and non-significant positive correlation with $\mathrm{K}(\mathrm{r}=0.218)$. The silt showed positive but non-significant correlation with available $\mathrm{N}(\mathrm{r}=0.072), \mathrm{K}$ $(r=0.047)$ and $S(r=0.104)$ while it showed negative and non-significant correlation with available $\mathrm{P}(\mathrm{r}=-0.056)$. The sand showed positive and non-significant correlation with available $\mathrm{P}(\mathrm{r}=0.262)$, negative correlation with $\mathrm{N}(\mathrm{r}=-0.066), \mathrm{K}(\mathrm{r}=-0.167)$ and $\mathrm{S}(\mathrm{r}=$ $0.040)$ but the values of correlation coefficients were statistically non-significant.

In conclusion, the present study was made to estimate available macronutrients $(\mathrm{N}, \mathrm{P}, \mathrm{K}$ and $\mathrm{S}$ some physico - chemical properties in soils of Udham Singh Nagar District of Uttarakhand. From the above findings it may be concluded that the soils of Udham Singh Nagar district are low in nitrogen, sufficient in phosphorus and in potassium, Except
Sitarganj, jaspur and bazpur samples were low in potassium, sufficient in sulphur except Rudrapur. The soil $\mathrm{pH}$ found slightly alkaline in Rudrapur, Gadarpur, Sitarganj and Bazpur, medium acidic in Khatima, slightly acidic in Kashipur and in neutral range in Jaspur district. Salinity effects mostly negligible, organic carbon is high in whole district except low in khatima and medium in Jaspur and Kashipur. A more detailed fertility survey is required to verify the deficiency of macro and micro nutrients in the region. Further, pot culture and field experiment are required to be undertaken in future to verify the validity of critical limits of these nutrients likely to be deficient in the study area.

\section{References}

Bower, C. A. and Wilcox, L. A. (1965). Soluble salts. In: black C.A. et al, (Ed.). Method of soil analysis, part 2, ASA, Inc. Madison, Wis, USA. Pp. 433-451.

Dixit A. K. (1992). Chemo-edaphological characterization of Bhabar-tarai plain transect soils of RamgangaKosiinterbasin. Thesis. Ph. D. (Soil Science) G. B. Pant Univ. of Agric. Tech., Pantnagar.

Hanway, J. J. and Hiedal, H. (1952). Soil analysis method used in lowa State Soil Testing Laboratory. Iowa Agric. (c.f. methods of soil analysis, part 2 Ed. C.A. Black, Medison Wisconsin). American Soc. Agron., 57: 1025-1027.

Kumar, S. (1988). Studies on the status of micronutrients in the soils of Bareilly division of Uttar Pradesh. M. Sc. Thesis, submitted to Govind Ballabh Pant Univ. of Agric. and Tech, Pantnagar.

Moodie, G. E.; Smith W. H. and McGreery, R. A. (1959). Laboratory Manual for Soil Fertility. Dept. Agron., Washington State College, USA. pp: 31-39. 
Murphy, J. and Riley, J. P. (1962).A modified single solution method for the determination of phosphate in natural waters.Anal.Chim.Acta. 27: 31-36.

Jackson, M. L. (1967). Soil chemical analysis. Prentice Hall of India (P) Ltd., New Delhi. pp. 183-192.

Olsen, S. R.; Cole, C. V.; Watanabe, F. S. and Dean, L. A. (1954). Estimation of available phosphrous in soils by extraction with sodium bicarbonate. USDA. Circ. 939 pp.

Muhr, G. R.; Datta, N. P.; Subraney, N. S.; Dever, F.; Lecy, V. K. and Donahue, R. R. (1963). Soiltesting of India.USAID Mission to India. 3(3): 87-92.

Shah, S. K. (1999). Distributin of nutrients in some soils of western Uttar Pradesh and their relationship with some soil properties. Thesis, M.Sc. G. B. Pant Univ. of Agric. and Tech., Pantnagar.

Walkley, A. and Black, C. A. (1934). An examination of different method for determining soil organic carbon and a proved modification of chromic acid titration method. Soil Sci., 37: 29-38.

Williams, C. H. and Steinbergs, A. (1959). Soil sulphur fractions as chemical indices of available sulphur in some Australian soils.Aust. J. Agric. Res. 10: 342-352.

Yuan, J. P., Peng, J., Yin, K. and Wang, J. H. 2011. Potential health-promoting effects of astaxanthin: A high-value carotenoid mostly from microalgae. Mol Nutr Food Res. 55: 150-165.

\section{How to cite this article:}

Vineet Kumar, Ajaya Srivastava, Shiv Singh Meena and Sarvesh Kumar. 2017. Availability of Macronutrients and their Relationship with some Soil Properties in Molisols of Udham Singh Nagar District of Uttarakhand, India. Int.J.Curr.Microbiol.App.Sci. 6(6): 234-240. doi: https://doi.org/10.20546/ijcmas.2017.606.028 